\title{
Applications for Aid and Assistance in Respect of Foreign Insolvency Proceedings in New Zealand since the Enactment of the Insolvency (Cross-Border) Act 2006 (NZ)
}

\section{Trish Keeper*}

This article analyses the discretion available to a New Zealand court to grant assistance in response to an application for inward assistance in relation to a cross-border insolvency (CBI) proceeding since the Insolvency (Crossborder) Act 2006 (NZ) (ICB Act) came into force in 2008. Specifically, the article considers the discretionary power given to the Courts under $s$ of the Act to provide aid and assistance. This section has been held to apply when an application in respect of an overseas foreign proceeding does not meet the requirements for the Model Law rules in Sch 1 of the Act. The Model Law rules are based on the United Nations Commission on International Trade's Model Law on Cross-Border Insolvency. Three High Court decisions to date have considered this discretion in $s$. The article identifies the factors that the courts have taken into account when deciding whether to provide aid and assistance under the provision. These are the policy objectives of the Act, the private international law principle of comity and the universalist approach to $\mathrm{CBI}$ at common law. The article then discusses these factors and whether international common law developments have altered the approach that New Zealand courts will take to future applications for aid and assistance under $s$. It also discusses the limits of $s 8$ in terms of the jurisdiction to remit New Zealand-located funds and assets and possible amendments to the ICB Act.

\section{INTRODUCTION}

The preamble to the 1997 United Nations Commission on International Trade's (UNCITRAL) Model Law on Cross-Border Insolvency (the UNCITRAL Model Law) ${ }^{1}$ describes cross-border insolvency (CBI) as insolvency that "arises when an insolvent entity has assets or debts in more than one state". The preamble continues that CBI issues can occur "not only between different countries, but also between different states within a federal system". ${ }^{2}$ The New Zealand Law Commission in its 1999 Report, ${ }^{3}$ which recommended New Zealand should adopt the UNCITRAL Model Law, also used this definition of CBI. ${ }^{4}$ The Law Commission observed that CBI issues are likely to arise as "the domestic insolvency laws of each state are likely to be different. Nevertheless, the administrator of the formal insolvency regime has a duty to realise assets of the insolvent entity for the benefit of all creditors of that entity, subject to any applicable domestic insolvency laws to the contrary". Subsequently, New Zealand enacted the Insolvency (Cross-Border) Act 2006 (NZ) (the ICB Act) to enshrine the UNCITRAL Model Law into New

\footnotetext{
* Senior Lecturer in Commercial Law, Victoria University of Wellington, New Zealand.

${ }^{1}$ The Model Law on Cross-Border Insolvency was adopted by the United Nations Commission on International Trade Law on 30 May 1997, and approved by the General Assembly of the United Nations on 15 December 1997.

${ }^{2}<$ http://www.uncitral.org/uncitral/en/uncitral_texts/insolvency/1997Model.html>

${ }^{3}$ New Zealand Law Commission, Cross-Border Insolvency: Should NZ Adopt the UNCITRAL Model of Cross-Border Insolvency?, Report No 52 (18 February 1999); UNICITRAL website, n 2.
}

${ }^{4}$ New Zealand Law Commission, n 3, [E6].

${ }^{5}$ New Zealand Law Commission, n 3, [E6]. 
Zealand Law. To date, the UNCITRAL Model Law has had moderate level of international acceptance, with 43 countries having legislation based on the Model Law at the time of writing. ${ }^{6}$ These include the United States, the United Kingdom, Australia, as well as New Zealand. ${ }^{7}$

The ICB Act is structured with the provisions of the UNCITRAL Model Law, including minor modifications for the New Zealand context, being located in Sch 1 to the Act. Sch 1 is expressly stated to be the law of New Zealand in the circumstances set out in Art 1 of the Schedule. ${ }^{8}$ Article 1, other than excluding applications in respect of registered banks ${ }^{9}$ that are subject to statutory management, ${ }^{10}$ provides that Sch 1 applies to both requests to a New Zealand court for outward and inward assistance. An application to a domestic court for outward assistance is when assistance is sought in a foreign state in connection with a domestic insolvency proceeding. A request for inward assistance is when a domestic court is asked to provide assistance in respect of an insolvency proceedings in a foreign state. ${ }^{11}$

The focus of this article is on requests to a New Zealand court to provide inward assistance, specifically when the request does not meet the conditions for assistance to be provided under the Model Law in Sch 1. In this circumstance, a court may have jurisdiction under s 8 of the Act itself. Section 8 reflects what used to be called an "order in aid procedure", which for Commonwealth countries originates from s 74 of the Bankruptcy Act 1869 (UK). ${ }^{12}$ Section 8(2) provides that New Zealand court may, at its discretion, act in aid of and be auxiliary to an overseas court in relation to a foreign insolvency proceeding. Similar aid and auxiliary provisions can be found in s 29 of the Bankruptcy Act 1966 (Cth) and s 581(2) and (3) of the Corporations Act 2001 (Cth). These provisions were retained in Australian law despite the introduction of the Cross-Border Insolvency Act (Cth) in 2008 and require an Australian court to provide assistance to the insolvency courts of certain prescribed countries, ${ }^{13}$ which includes New Zealand. Both of the Australian regimes also provide that the courts have a discretionary power to provide assistance to courts from other jurisdictions. ${ }^{14}$ Murray and Harris in Keay's Insolvency Law note with respect to requests from non-prescribed countries that although "there is no initial assumption that the Australian court is bound to give all the assistance it can, ... the international rules of comity between courts will generally mean that the Australian court will make the orders sought". ${ }^{15}$

The article consists of six parts. After this first introductory part, Part II outlines the sources of jurisdiction available to New Zealand courts to provide inward assistance prior to the enactment of the ICB Act and the rationale for its adoption. The next part briefly examines the key definitions for the Model Law

\footnotetext{
${ }^{6}$ The UNCITRAL website also states that although 43 countries have adopted the Model Law, it has in fact been applied in 45 jurisdictions as both British Virgin Islands and Gibraltar have adopted it, but are overseas territories of the United Kingdom, $<$ http://www.uncitral.org/uncitral/en/uncitral_texts/insolvency/1997Model_status.html >.

${ }^{7}$ The United States adopted the Model Law in Chapter 15 of the Bankruptcy Code in 2005 (Bankruptcy Abuse Prevention and Consumer Protection Act of 2005, Pub L No 108-09, Title VIII, §§ 801-802; Title XV, 119 Stat 23, §§ 134-146); The United Kingdom adopted the Cross-Border Insolvency Regulations 2006 (No 1030) and the Australian Cross-Border Insolvency Act 2008 (Cth).

${ }^{8}$ Insolvency (Cross-border) Act 2006 (NZ) s 7.

${ }^{9}$ A registered bank is one that is registered within the meaning of Reserve Bank of New Zealand Act 1989 (NZ) s 2(1).

${ }^{10}$ Statutory management under Reserve Bank of New Zealand Act 1989 (NZ) Pt 5.

${ }^{11}$ See Richard Sheldon (ed), "Introduction" in Cross-Border Insolvency (Bloomsbury Professional, $4^{\text {th }}$ ed, 2015) 8.

${ }^{12}$ Williams v Simpson (No 5) [2011] 2 NZLR 380 (HC), [77] (Heath J). Also see Callender Sykes and Co v Colonial Secretary of Lagos [1891] AC 460 (PC), 467 where the Court confirmed that the provision applied to all Commonwealth countries.

${ }^{13}$ Bankruptcy Act 1966 (Cth) s 29(5); Bankruptcy Regulations 1996 (Cth) reg 3.01; Corporations Act 2001 (Cth) s 581(2); and Corporations Regulations 2001 (Cth) reg 5.6.74. See, eg, Re Cooksley (2017) 15 ABC(NS) 352; [2017] FCA 1193 where a New Zealand bankruptcy was recognised in Australia to allow the New Zealand Official Assignee to recover income contributions from a New Zealand bankrupt who was living and working in Australia; Re Edelsten (2014) 320 ALR 506; [2014] FCA 1112 discussed the jurisdiction of an Australian court to provide assistance under both Art 21 of the with respect to a request to provide assistance to a US trustee in bankruptcy under Cross-Border Insolvency Act 2008 (Cth) Art 21; Bankruptcy Act 1966 (Cth) s 29.

${ }^{14}$ Bankruptcy Act 1966 (Cth) s 29(3); Corporations Act 2001 (Cth) s 581(3).

${ }^{15}$ Micheal Murray and Jason Harris, Keay's Insolvency: Personal and Corporate Law and Practice (Lawbook Co, 10 ${ }^{\text {th }} \mathrm{ed}, 2018$ ) 239.
} 
in Sch 1 that apply in respect of an application to provide inward assistance. Part IV examines how courts have interpreted the discretion available to them under s 8 of the Act which has been held to apply only when a request for inward assistance does not qualify for assistance under the Schedule. This part reviews the three cases to consider $\mathrm{s} 8$ and considers the factors identified by the courts which inform judicial discretion to provide assistance. The penultimate part discusses the implications of these decisions, including the potential implications of recent decisions that have placed constraints on the judicial power to provide assistance. It also discusses the limitations of providing assistance under s 8 in comparison to the Model Law in Sch 1. The final part is the conclusion.

\section{Request for Inward Assistance Prior to the Insolvency (Cross- BORDER) ACT 2006 (NZ)}

\section{A. Statutory Jurisdiction}

Prior to the ICB Act coming into force on the 24 July $2008^{16}$ the jurisdiction of New Zealand courts to provide assistance in response to a request for inward assistance from a foreign court or insolvency practitioner derived from both statute and the common law. ${ }^{17}$

The principal source of jurisdiction for inward requests with respect to an overseas bankrupt individual was s 135(1) of the Insolvency Act 1967 (NZ). This section corresponded to s 29 of the Bankruptcy Act 1966 and provided that the High Court had jurisdiction to act in aid of, and to be auxiliary to, any court of any Commonwealth country, other than New Zealand which had jurisdiction in the bankruptcy matters. The High Court simply needed to receive an order requesting aid issued by a Commonwealth court for it to consider providing the requested matters as if the matters had arisen in New Zealand. In addition, s 135(2) gave a discretionary power to the court to provide, as its think fit, jurisdiction to exercise the powers specified in s 135(1), at the request of a court from a non-Commonwealth country. ${ }^{18}$

However, there was not an equivalent "aid and assistance" provision in the Companies Act 1993 (NZ) as the High Court, under the s 342 (prior to amendment in 2008), ${ }^{19}$ only had jurisdiction to provide inward assistance by liquidating any overseas company that had assets in New Zealand. The same laws as applied to domestic companies applied to the liquidation, ${ }^{20}$ which potentially could result in unequal treatment between domestic and overseas creditors. ${ }^{21}$ Furthermore, the liquidation of the New Zealand assets usually necessitated the appointment of a New Zealand liquidator. In Gavigan v Australian Memory Pty Ltd (in liq) (Gavigan), ${ }^{22}$ the Court observed that it was "unlikely and undesirable" for a court to appoint an overseas liquidator to be a domestic liquidator. ${ }^{23}$ Generally, it was considered that the pre-2008 version of s 342 restricted the ability of the court to provide assistance and in many instances the section was "of limited practical assistance to a liquidator/trustee of a foreign-based corporation which has assets in New Zealand". ${ }^{24}$

\footnotetext{
${ }^{16}$ The Insolvency (Cross-border) Act 2006 (NZ) No 57 came into force on 24 July 2008 by virtue of the Insolvency (Cross-border) Commencement Order 2008 (NZ) (SR 2008/171).

${ }^{17}$ New Zealand Law Commission, n 3, 29 identified three distinct mechanisms - two were statutory and the third, the common law principle of comity.

${ }^{18}$ See Paul Heath, "International Insolvencies: A New Zealand Perspective" (1998) 6 Insolv LJ 90; New Zealand Law Commission, n 3, [31]-[48] for full account of the operation of Insolvency Act 1967 (NZ) s 135.

${ }^{19}$ Section 342 was amended from 24 July 2008, contemporaneously with the Insolvency (Cross-border) Act 2006 (NZ) coming into force. The provision now is restricted to applications to liquidate overseas companies under the Companies Act 1993 (NZ) in accordance with Companies Act 1993 Pt 16.

${ }^{20}$ Companies Act 1993 (NZ) s 342.

${ }^{21}$ For example, the rules applying to preferential creditors as set out in Companies Act 1993 (NZ) Sch 7 may be more favourable to local creditors than under the law of an overseas jurisdiction.

${ }^{22}$ Gavigan v Australian Memory Pty Ltd (in liq) (1997) NZCLC 261,449.

${ }^{23}$ Gavigan v Australian Memory Pty Ltd (in liq) (1997) NZCLC 261,449, 261,452.

${ }^{24}$ Jennifer Sutton, "Cross-border Insolvency: The New Zealand Position” (1998) 4 New Zealand Business Law Quarterly 209, 211; Also see Heath, n 18, 94.
} 


\section{B. Comity and the Common Law}

New Zealand courts also were willing on occasion to rely on the principle of comity when the above described limited statutory scheme did not apply. ${ }^{25}$ Heath and Whale on Insolvency state that "comity refers to the deference that courts give to the decisions of overseas courts of competent jurisdiction, and the principle that those decision should be given effect provided that doing so does not offend public policy or infringe upon the rights and entitlements of local creditors". ${ }^{26}$ Sutton in 1998, after reviewing New Zealand case law, observed that New Zealand courts undertook in effect a two-stage assessment before agreeing to provide judicial assistance on the grounds of comity. ${ }^{27}$ First, a court needed to consider whether the foreign corporate insolvency should be recognised by New Zealand courts. Generally, she observed that recognition rules with respect to stage one were well established. Recognition will generally be given to the liquidation of a foreign company in its place of incorporation. A second ancillary question at the first stage is for the court to ascertain whether the liquidator or trustee for that corporation has been appropriately appointed under the rules that apply in that country in question. ${ }^{28}$ If so, the liquidator or trustee will generally be recognised as having authority to act on behalf of that company in relation to its overseas assets. ${ }^{29}$ Moreover, only in a limited range of circumstance might a New Zealand court refuse to recognise foreign proceedings, including that the proceedings must constitute a fraud, are in breach of natural justice, contrary to public policy or relate to proceedings that are not final. ${ }^{30}$

The second question step required the court to consider whether it should provide the assistance sought in respect of a foreign corporate insolvency. Paterson $\mathrm{J}$ in 1997 in Gavigan ${ }^{31}$ expressed the Court's approach to this issues as follows:

In normal circumstances, there should be one set of liquidators charged with the responsibility of getting in the assets of the company and distributing them in accordance with the law. It follows that in a country which is not the place of residence of the company in liquidation, and where that company has assets, the underlying principle upon which the Courts should act is the liquidators appointed in the company's country of residence should be recognised as having the right to administer the assets of the company. Further, the Courts should actively assist the liquidators in carrying out such duties. The advantages of such a principle are that there is no duplication of processes and normally there would be a reduction in administrative expenses.

His Honour in Gavigan considered with approval an earlier decision of the High Court in Turners \& Growers v The Ship "Cornelis Verolme" (Turners \& Growers), ${ }^{32}$ a case involving a group of companies that were placed in bankruptcy in Belgium, with a Belgium commercial judge and trustees appointed to oversee the procedure. At the time of the bankruptcy, the group of companies had a number of ships located around the world, including the Cornelis Verolme that had been seized in New Zealand. The trustees obtained from a Belgian court a request that the ship be released into their hands and that the Belgian-based trustees and Belgian courts determine the order of priorities in respect of the various claims by creditors. Specifically, the order requested that the ship not be sold in New Zealand to meet the claims of New Zealand-based creditors, as this would prejudice other creditors. Williams J considered that comity required him to recognise the liquidation of a foreign corporation in its place of incorporation and the valid appointment of a foreign representative unless there were good reasons otherwise. These included that there were no positive law in New Zealand to the contrary.

\footnotetext{
${ }^{25}$ New Zealand Law Commission, n 3, [21]; Heath, n 18, 94.

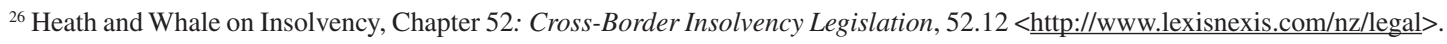

${ }^{27}$ Sutton, n 24, 211.

${ }^{28}$ Sutton, n 24, 211.

${ }^{29}$ Bank of Ethiopia v National Bank of Egypt and Liguori [1937] 1 Ch 513, 524.

${ }^{30}$ Sutton, n 24, 211.

${ }^{31}$ Gavigan v Australian Memory Pty Ltd (in liq) (1997) NZCLC 261,449, 261,452.

${ }^{32}$ Turners \& Growers $v$ The Ship "Cornelis Verolme" [1997] 2 NZLR 110 (HC).
} 
In a New Zealand decision earlier that year, Fournier v The Ship "Margaret Z" (Fournier), ${ }^{33}$ the Court had found against a claim based on comity because the foreign court (9th Circuit Court of Appeals in relation to the foreign territory of Guam) would treat wages of the seamen on the seized ship as not being subject to the same level of protection as would be the situation in New Zealand. This case was distinguished by Williams $\mathrm{J}$ in Turners \& Growers on a number of factual grounds, including that the latter case did not involve any $\mathrm{Ch} 11$ issue, as was the case in Fournier. Nonetheless, the conflicting results in Turners \& Growers and Fournier decisions do illustrate the difficulties that can arise when international law principles, such as comity, are applied to the often very complex backgrounds of CBI cases.

These cases also illustrate that New Zealand courts, in the absence of statutory jurisdiction prior to the ICB Act, were willing to consider applications for recognition and assistance in relation to foreign corporate insolvencies based on the private law principle of comity. As discussed later in this article, this principle continues to inform New Zealand courts when they are exercising their discretion to provide assistance in response to an application that falls outside of the scope of the Sch 1, Model Law.

\section{Pressure for Reform: UNCITRAL Model Law and the New Zealand Law Commission}

The opposite outcomes in Gavigan and Turners \& Growers compared to the Fournier decision gave strength to calls for a reform of New Zealand's law in this area, ${ }^{34}$ calls that were strengthened by the adoption of UNCITRAL Model Law by the United Nations Commission on International Trade Law in 1997. The Model Law was a response to growing international concerns about the ability of individual nations to adequately deal with CBI claims. These concerns ultimately led to UNCITRAL, in close co-operation with INSOL International, proposing the creation of a UNCITRAL Model Law. This was finalised in 1997 after a series of reports and draft model laws. ${ }^{35}$ The preamble to the UNCITRAL Model Law states that it is a legislative text that nation states are recommended to incorporate into their national law. ${ }^{36}$

These pressures led to a request to the New Zealand Law Commission to consider whether New Zealand should adopt the UNCITRAL Model Law. ${ }^{37}$ The Law Commission, after setting out factors for and against adoption including the inadequacy of the current legislation, including that New Zealand had a significant amount of foreign investment, recommended on balance the adoption of the UNCITRAL Model Law. ${ }^{38}$ The Law Commission also recommended that the Model Law in the proposed Act should become the sole pathway for New Zealand courts to provide assistance and that the existing statutory provisions in the Insolvency Act and the Companies Act 1993 should be repealed contemporaneously with the bringing into force of the Model Law. The rationale for this recommendation was that existence of only one CBI pathway would lead to a more uniform approach. ${ }^{39}$ The second part of this recommendation was followed as the existing statutory provisions (as outline above) were either amended or repealed before or when the ICB Act came into force.$^{40}$ However, Parliament decided to include in the Act a broad request for assistance and aid provision in s 8 in addition to the Model Law regime. This was a deliberate policy

\footnotetext{
${ }^{33}$ Fournier v The Ship "Margaret Z” [1997] 1 NZLR 629 (HC).

${ }^{34}$ Heath, n 18; Sutton, n 24.

${ }^{35}$ For a detailed summary of the events leading up to the UNCITRAL Model Law, see Jenny Clift, "UNCITRAL Model Law on Cross-Border Insolvency - A Legislative Framework to Facilitate Co-ordination and Co-operation in Cross-Border Insolvency" (2004) 12 Tulane Journal of International and Comparative Law 307, 312-315.

${ }^{36}$ Model Law on Cross-Border Insolvency, n 1, [19].

${ }^{37}$ New Zealand Law Commission, n 3, ix.

${ }^{38}$ New Zealand Law Commission, n 3 [E6].

${ }^{39}$ New Zealand Law Commission, n 3, [116].

${ }^{40}$ Insolvency (Cross-border) Act 2006 (NZ) s 13 amended Companies Act 1993 (NZ) s 342 to only provide a mechanism for an overseas company to be liquidated under the Act. The Insolvency Act 1967 (NZ) was replaced by the Insolvency Act 2006 (NZ) from 3 December 2006. There is no equivalent provision in the Insolvency Act 2006 (NZ).
} 
decision by Parliament "to retain an old remedy in order to ensure that that co-operation did not wither through a lacuna in sch $1 " .{ }^{41}$ The focus of this article is $\mathrm{s} 8$.

\section{The Insolvency (Cross-Border) Act 2006}

As stated above, the ICB Act is structured with the provisions of the UNCITRAL Model Law, including minor modifications for the New Zealand context, being set out in Sch 1 to the Act (Sch 1 Model Law). The Preamble to the Schedule states that its purpose is to provide effective mechanisms for dealing with cases of CBI to promote certain objectives. These include greater co-operation between New Zealand courts and overseas jurisdictions in matters of CBI, greater legal certainty for trade and investment, and fairness and efficiency to protect the interests of all creditors. ${ }^{42}$

For the Sch 1 Model Law to apply to requests for inward assistance from a New Zealand court ${ }^{43}$ the assistance must be sought by a "foreign court" or a "foreign representative" in connection with a "foreign proceeding". Each of these terms are separately defined in Sch 1 in language consistent with that found in the UNCITRAL Model Law. ${ }^{44}$ For example, Art 17 provides that the New Zealand High Court shall only recognise a foreign proceeding if it is a "foreign main proceeding" or a "foreign non-main proceeding". Accordingly, foreign proceedings are either "main" or "non-main". A foreign main proceeding is the state where the debtor has its centre of main interest (COMI). A foreign non-main proceeding is where the debtor has an "establishment" and this is further defined as meaning any place of operations where the debtor carries out a non-transitory economic activity with human means and goods or services ${ }^{45}$ If an overseas request for assistance does not qualify as either a foreign main or foreign non-main proceeding, then the provision of assistance under Sch 1 is precluded.

\section{Section 8: Requests for Aid ANd Assistance}

\section{A. Conditions for Relief under s 8}

This was the situation in Williams $v$ Simpson (No 5) (Williams $v$ Simpson) ${ }^{46}$ when a trustee in bankruptcy (who had been appointed by an English Court) applied to the New Zealand High Court under the ICB Act for an order recognising the English bankruptcy as a foreign main proceeding or a foreign non-main proceeding. The bankrupt, a Mr Reeves, had worked in London, but had retired to New Zealand and considered New Zealand his home. On the facts of the case, the Court found that the English proceedings were neither foreign main proceedings, nor foreign non-main proceedings. ${ }^{47}$ Accordingly, the Court held that it could not provide assistance under the terms of Sch 1 of the ICB Act, but was then willing to consider whether the Court could provide assistance under s 8 of the Act. Section 8 provides:

8 High Court to act in aid of overseas courts

(1) This section applies to a person referred to in article 1(1) of Schedule 1.

(2) If a court of a country other than New Zealand has jurisdiction in an insolvency proceeding and makes an order requesting the aid of the High Court in relation to the insolvency proceeding of a person to

\footnotetext{
${ }^{41}$ Williams v Simpson (No 5) [2011] 2 NZLR 380 (HC).

${ }^{42}$ Insolvency (Cross-border) Act 2006 (NZ) Sch 1, Preamble (a)-(c).

${ }^{43}$ Insolvency (Cross-border) Act 2006 (NZ) Sch 1, Ch II, III.

${ }^{44}$ Insolvency (Cross-border) Act 2006 (NZ) Sch 1, Art 2(2) defines a "foreign court" as meaning a judicial or other authority competent to control or supervise a foreign proceeding; a "foreign representative" as meaning a person or body, including one appointed on an interim basis, authorised in a foreign proceeding to administer the reorganisation or the liquidation of the debtor's assets or affairs or to act as a representative of the foreign proceeding; and a "foreign proceeding" as meaning a collective judicial or administrative proceeding in a foreign State ... pursuant to a law relating to insolvency in which proceeding the assets and affairs of the debtor are subject to control or supervision by a foreign court, for the purpose of reorganisation or liquidation.

${ }^{45}$ Insolvency (Cross-border) Act 2006 (NZ) Sch 1, Art 2(f).

${ }^{46}$ Williams v Simpson (No 5) [2011] 2 NZLR 380 (HC).

${ }^{47}$ Williams v Simpson (No 5) [2011] 2 NZLR 380 (HC), [41]-[49], [50]-[66].
} 
whom this section applies, the High Court may, if it thinks fit, act in aid of and be auxiliary to that court in relation to that insolvency proceeding.

(3) In acting in aid of and being auxiliary to a court in accordance with subsection (2), the High Court may exercise the powers that it could exercise in respect of the matter if it had arisen within its own jurisdiction.

Before considering the section in detail, it is worth noting that the section does not in fact expressly provide that any exercise by a court of its discretion is conditional upon an application being ineligible for relief pursuant to Sch 1 Model Law. Notwithstanding this drafting, this was the approach taken by the Court in Williams $v$ Simpson ${ }^{48}$ and has been followed in the later High Court decisions of Heath J in Re Batty (Trustees in Bankruptcy of Reeves $v$ Reeves (Re Batty) ${ }^{49}$ and Leeds $v$ Richards. ${ }^{50}$ Although this interpretation is not supported on a literal view of the section itself, this approach to $\mathrm{s} 8$ is sensible. It means automatic first priority is afforded to the Sch 1 Model Law and this creates certainty for overseas courts and practitioners. It also avoids overlapping pathways for relief as has happened in Australia since it adopted the UNCITRAL Model Law in Cross-Border Insolvency Act 2008, while retaining the existing aid and auxiliary provisions in s 29 of the Bankruptcy Act 1966 and ss 580 and 581 of the Corporations Act 2001. ${ }^{51}$

The only express requirement for assistance to be available under s 8 is where the overseas court has requested the aid of the High Court to assist a "person" to whom the section applies. This "person" is stated to be the same "person" as defined in Art 1(1) of Sch 1. Although the wording is not entirely helpful, this person can only be the foreign representative in Art 1(1)(a). ${ }^{52}$ A foreign representative is a "person or body, including one appointed on an interim basis, authorised in a foreign proceeding to administer the reorganisation or the liquidation of the debtor's assets or affairs or to act as a representative of the foreign proceeding".

\section{B. Section 8 Discretion: Three Factors}

Williams $v$ Simpson was the first case which considered the scope of the discretion in s 8(2) and Heath J noted that there are no criteria in the provision itself to guide a court in this exercise. After reviewing the background to the Act and the provision itself, he identified three factors that he considered should inform any decision by a court to provide assistance pursuant to the section. These as the express purposes of the Act, the acceptance of the principle of comity in New Zealand and common law principles of international insolvency law. A test that has been followed in the two subsequent cases to consider the discretion in s $8 .^{53}$ The next part of this article discusses each of the factors separately.

\section{Purpose}

Section 3 sets out the two purposes for the $I C B$ Act. The first is to adopt the UNCITRAL Model. ${ }^{54}$ However, the Court focused on the second purpose in s 3(b) which is to provide a "framework for facilitating insolvency proceedings" in certain CBI situations. ${ }^{55}$ His Honour observes that this purpose is "just

\footnotetext{
${ }^{48}$ In reaching this conclusion, his Honour considered and applied the leading overseas decisions on the meanings of COMI and establishment in the context of the UNCITRAL Model law.

${ }^{49}$ Batty (Trustees in Bankruptcy of Reeves) v Reeves [2015] BCC 6858; [2015] NZHC 908.

${ }^{50}$ Leeds v Richards [2016] NZAR 1405; [2016] NZHC 2314.

${ }^{51}$ See Gerald McCormack and Anil Hargovan, "Australia and the International Insolvency Paradigm" (2015) 37 Sydney Law Review 389, 407-408 for a discussion of the potential for confusion arising due to overlapping insolvency procedures.

${ }^{52}$ Williams v Simpson (No 5) [2011] 2 NZLR 380 (HC).

${ }^{53}$ Batty (Trustees in Bankruptcy of Reeves) v Reeves [2015] BCC 6858; [2015] NZHC 908; Leeds v Richards [2016] NZAR 1405; [2016] NZHC 2314.

${ }^{54}$ The first purpose in s 3(a) is to implement the Model Law on Cross-Border Insolvency adopted by the United Nations Commission on International Trade Law on 30 May 1997, and approved by the General Assembly of the United Nations on 15 December 1997 as amended and supplemented in order to apply to New Zealand.

${ }^{55}$ Insolvency (Cross-border) Act 2006 (NZ) s 3(b) identifies these situations are when person is subject to insolvency administration (whether personal or corporate) in one country, but has assets or debts in another country; or more than one insolvency administration has commenced in more than one country in relation to a person.
} 
as applicable to section 8, as to sch $1 "{ }^{56}$ Later in the judgment, Heath $\mathrm{J}$ focused on the facilitation aspect of the purpose, when he observed that together with considerations based on comity, common law principles and "Parliament's intention to encourage efficient facilitation of cross-border insolvency proceedings" a basis for s 8 relief emerges. ${ }^{57}$

\section{Principle of Comity}

As outlined above, New Zealand courts had been willing to provide assistance on the basis of the private international law principle of comity prior to the enactments of the ICB Act..$^{58}$ Notwithstanding the change in the statutory framework once after the Act came into force, Heath $\mathrm{J}$ took the approach that comity continues to be one basis on which relief may be fashioned. He observed that in countries with a similar provision to $\mathrm{s} 8$, the Court "will generally exercise its discretion in favour of giving assistance unless there is some compelling reasons not to do so" ${ }^{59}$ Furthermore, his Honour quoted with approval the following statement by the Second Circuit of the US Court of Appeals in Curnard Steamship Co Ltd $v$ Salen Reefer Services $A B,{ }^{60}$ as to the meaning of comity in the context of a collective insolvency regime:

The granting of comity to a foreign bankruptcy proceeding enables the assets of a debtor to be dispersed in an equitable, orderly, and systematic manner, rather than in a haphazard, erratic or piecemeal fashion. Consequently, American courts have consistently recognized the interest of foreign courts in liquidating or winding up the affairs of their own domestic business entities.... It has long been established that foreign trustees in bankruptcy were granted standing as a matter of comity to assert the rights of the bankrupt in American courts. ... Although the early cases upheld the priority of local creditors' attachments ... the modern trend has been toward a more flexible approach which allows the assets to be distributed equitably in the foreign proceeding.

His Honour noted that the justification for granting comity in international insolvency proceedings is to ensure that a debtor's property is disposed of as quickly as possible for the benefit of all creditors with an interest in the distribution of assets. ${ }^{61}$ Further, that it is also consistent with economies of scale as the "having of a single administrator on behalf of all creditors with a view, subject to priorities accorded by national legislation, to ensuring maximum returns to creditors on a pari passu basis". ${ }^{62}$

\section{Principles of International Insolvency Law}

The third factor identified by Heath $\mathrm{J}$ was the "universalist" approach to international insolvency law as asserted by Lord Hoffman on behalf of the Privy Council in Cambridge Gas Transportation Corp v Official Committee of Unsecured Creditors of Navigator Holdings (Cambridge Gas). ${ }^{63}$ Cambridge Gas was decided before the UNCITRAL Model Law was adopted by the United Kingdom and its territories. It arose after a Bankruptcy Court in the United States sent a Letter of Request to the High Court of Justice

\footnotetext{
${ }^{56}$ Williams v Simpson (No 5) [2011] 2 NZLR 380 (HC), [73].

${ }^{57}$ Williams v Simpson (No 5) [2011] 2 NZLR 380 (HC), [79]. See also Williams v Simpson (No 7) HC HAM CIV2010-419-1174 (10 November 2010) [16] where Heath J specifically identified the purposes as stated in s 3(b) as informative to interpret s 8 of the Act.

${ }^{58}$ See Part II B of this article.

${ }^{59}$ Williams v Simpson (No 5) [2011] 2 NZLR 380 (HC), [75].

${ }^{60}$ Curnard Steamship Co Ltd v Salen Reefer Services AB, 773 F 2d 452 (1985).

${ }^{61}$ Compare Fournier v The Ship "Margaret Z" [1997] 1 NZLR 629 (HC) where an argument based on comity failed to have the High Court recognise an appellate decision of the $9^{\text {th }}$ Circuit Court of Appeals; Turners \& Growers v The Ship "Cornelis Verolme" [1997] 2 NZLR 110 (HC), 122-123 (Williams J) where Williams J held that the principles of comity required him to recognise and give assistance to a Belgium court.

${ }^{62}$ Williams v Simpson (No 5) [2011] 2 NZLR 380 (HC), [76], citing with approval the New Zealand Law Commission, n 3, [24].

${ }^{63}$ Cambridge Gas Transportation Corp v Official Committee of Unsecured Creditors of Navigator Holdings Plc [2007] 1 AC 508; [2006] UKPC 26, (Hoffman J) referring to the aspiration of the universalist approach. This is sometime referred to as "modified universalism" following Lord Hoffman's judgment in Re HIH Casualty \& General Insurance Ltd [2008] 1 WLR 852, [30]; [2008] UKHL 21, where he referred to the "principle of (modified) universalism which has been the golden thread running through English cross-border insolvency law since the eighteenth century”.
} 
of the Isle of Man asking for assistance in giving effect to a plan and confirmation order made under Ch 11 of the US Bankruptcy Code. Although at first instance the request was refused, the Manx Court of Appeal reversed this decision and the reversal was upheld by the Privy Council. As the Isle of Man did not have an applicable statutory order-in-aid provision, it was necessary for the Privy Council to rely on common law principles.

The key paragraphs of Lord Hoffman from Cambridge Gas which Heath $\mathrm{J}$ quoted with approval in Williams $v$ Simpson are as follows: ${ }^{64}$

[15] .... The important point is that bankruptcy, whether personal or corporate, is a collective proceeding to enforce rights and not to establish them. Of course, as Brightman LJ pointed out in Re Lines Bros Ltd [1982] 2 All ER 183 at 194-195, [1983] Ch 1 at 20, it may incidentally be necessary in the course of bankruptcy proceedings to establish rights which are challenged: proofs of debt may be rejected or there may be a dispute over whether or not a particular item of property belonged to the debtor and is available for distribution. There are procedures by which these questions may be tried summarily within the bankruptcy proceedings or directed to be determined by ordinary action. But these again are incidental procedural matters and not central to the purpose of the proceedings.

[16] The English common law has traditionally taken the view that fairness between creditors requires that, ideally, bankruptcy proceedings should have universal application. There should be a single bankruptcy in which all creditors are entitled and required to prove. No one should have an advantage because he happens to live in a jurisdiction where more of the assets or fewer of the creditors are situated....

[17] This doctrine may owe something to the fact that eighteenth and nineteenth centuries Britain was an imperial power, trading and financing development all over the world. It was often the case that the principal creditors were in Britain but many of the debtor's assets were in foreign jurisdictions. Universality of bankruptcy protected the position of British creditors. Not all countries took the same view. ... But universality of bankruptcy has long been an aspiration, if not always fully achieved, of United Kingdom law. And with increasing world trade and globalisation, many other countries have come round to the same view.

Heath $\mathrm{J}$ then observed, that irrespective of the fact that the principles set out in Cambridge Gas were only applied by two of the five Law Lords in the subsequent 2008 House of Lords decision in $\mathrm{Re} H I H$ Casualty \& General Insurance Ltd, ${ }^{65}$ the Cambridge Gas principles applied in New Zealand to inform a court in any decision to grant assistance under s 8 of the ICB Act. Heath J continued that "there must, in my view, be some compelling reason why a universalist approach should not be applied on a s 8 request". ${ }^{66}$ This is an identical observation to that made by his Honour with respect to the principle of comity, although this likely reflects the overlapping, albeit not "completely synonymous" 67 nature of the two principles. Indeed the Court observed, with respect to common law principles, that "such principles are akin to those considered when questions of comity arise". ${ }^{6}$

Accordingly, in Williams $v$ Simpson the Court held that the principles expressed by Lord Hoffmann in Cambridge Gas should be taken into account whenever a court is exercising its discretion in s 8 of the $I C B$ Act. In addition to these principles, the statutory purpose of providing a framework to facilitate assistance and comity. Comity, together with Art 22(1) of Sch 1 requires that a court must be satisfied in any decision to provide aid under s 8 that "the interests of creditors and other interested parties, including the debtor, are adequately protected" before making any order. ${ }^{69}$ As discussed in the next part of this article, this approach has been followed with approval by the Federal Court of Australia and subsequent cases New Zealand that have considered the provision.

\footnotetext{
${ }^{64}$ Williams $v$ Simpson (No 5) [2011] 2 NZLR 380 (HC), [78].

${ }^{65}$ Re HIH Casualty \& General Insurance Ltd [2008] 1 WLR 852; [2008] UKHL 21.

${ }^{66}$ Williams v Simpson (No 5) [2011] 2 NZLR 380 (HC), [83].

${ }^{67}$ Andrew Godwin, Timothy Howse and Ian Ramsay, "The Inherent Power of Common Law Courts to Provide Assistance in Crossborder Insolvencies: From Comity to Complexity" (2017) 26 International Insolvency Review 5, 9.

${ }^{68}$ Williams v Simpson (No 5) [2011] 2 NZLR 380 (HC), [79].

${ }^{69}$ Williams v Simpson (No 5) [2011] 2 NZLR 380 (HC), [85]; Williams v Simpson (No 7) HC HAM CIV2010-419-1174 (10 November 2010) [14].
} 


\section{Developments after Williams v Simpson}

Shortly after the decision in Williams $v$ Simpson, the Federal Court of Australia in Gainsford $v$ Tannenbaum (Gainsford) ${ }^{70}$ approved Heath J's endorsement of Hoffman J's observations with respect to the universalist approach in Cambridge Gas as informing the discretion to provide assistance under New Zealand law. Gainsford concerned similar circumstances to Williams v Simpson, as it related to a highly mobile professional individual who had carried on business in South Africa before relocating to Australia. The foreign proceedings, namely a South African bankruptcy, were found to be neither a foreign main proceeding, nor a foreign non-main proceeding under the Australian Cross-Border Insolvency Act 2008. Instead, the Court was willing under its discretion in s 29 of the Bankruptcy Act 1966 to provide aid and assistance to the South African proceedings. Subsequently, McCormack and Hargovan ${ }^{71}$ criticised the adoption of universalist approach in Tannenbaum on the basis that Lord Hoffmann in Cambridge Gas was "talking implicitly about recognising the primacy and universality of insolvency proceedings that emanated from a jurisdiction where the debtor had its domicile, or in modern terminology, "centre of main interests"". ${ }^{72}$ As the debtor in Gainsford had been held not to have COMI in South Africa, McCormack and Hargovan assert that Cambridge Gas provided no authority for recognising the South African proceedings. Indeed as the debtor was resident in Australia, then "arguably the main bankruptcy forum should have been in Australia". ${ }^{73}$

The same criticism can be levelled at Heath J's approach in Williams $v$ Simpson given that the bankrupt, Reeves, COMI had been held not to be in England. However, in 2015 Heath $\mathrm{J}$ in $R e$ Batty ${ }^{74}$ reaffirmed that a universalist approach ${ }^{75}$ as espoused in Cambridge Gas, continues to inform any response by a New Zealand court to a request under s 8 . In this case his Honour noted that this approach continued to apply in New Zealand despite the fact that many of its principles "ha[d]been discredited"76 by both the Supreme Court of the United Kingdom in Rubin v Eurofinance $S A^{77}$ and the Privy Council in PricewaterhouseCoopers $v$ Saad Investments Ltd ${ }^{78}$ and Singularis Holdings Ltd v PricewaterhouseCoopers (Singularis). ${ }^{79}$ Re Batty concerned an application from a representative appointed by an English court to be the insolvency representative for the debtor's estate. The foreign representative had applied to the High Court in New Zealand for recognition of the proceedings commenced in England and for an order enabling the representative to gain access to the records of a bank account that the debtor operated in New Zealand. It was believed that the proceeds of sale for a property formerly owned by the debtor in England had been transferred to this account. Heath $\mathrm{J}$ adopted his reasoning from the earlier decision of Williams $v$ Simpson $^{80}$ to find that the proceedings in England did not fall within the definition of a main, or non-main foreign proceedings under the Sch 1 Model Law and accordingly was required to consider the provision of assistance under s 8 of the ICB Act. In addressing the issue of universality Heath $\mathrm{J}$ stated (footnotes removed):

[11] ... I have considered whether there is anything in the most recent judgment of the Privy Council, Singularis Holdings Ltd $v$ PricewaterhouseCoopers that might militate against the grant of relief in favour of Mr Batty. I am satisfied that there is not.

\footnotetext{
${ }^{70}$ Gainsford v Tannenbaum (2012) 216 FCR 543; [2012] FCA 904.

${ }^{71}$ McCormack and Hargovan, n 51.

${ }^{72}$ McCormack and Hargovan, n 51, 408.

${ }^{73}$ McCormack and Hargovan, n 51, 409.

${ }^{74}$ Batty (Trustees in Bankruptcy of Reeves) v Reeves [2015] BCC 6858; [2015] NZHC 908.

${ }^{75}$ Williams v Simpson (No 5) [2011] 2 NZLR 380 (HC), fn 18, Heath J observed that he used the term "universalist" as a shorthand expression to capture the term "modified universalism" and that his use of the term should not be regarded as broader than that contemplated in the Singularis judgment.

${ }^{76}$ Batty (Trustees in Bankruptcy of Reeves) v Reeves [2015] BCC 6858, [11]; [2015] NZHC 908.

${ }^{77}$ Rubin v Eurofinance SA [2013] 1 AC 236; [2012] UKSC 46.

${ }^{78}$ PricewaterhouseCoopers v Saad Investments Co Ltd [2014] 1 WLR 4482; [2014] UKPC 35.

${ }^{79}$ Singularis Holdings Ltd v PricewaterhouseCoopers [2015] AC 1675; [2014] UKPC 36.

${ }^{80}$ Williams v Simpson [2011] 2 NZLR 380 (HC).
} 
[12] Section 8(3) authorises this Court to make an order that it could exercise if the issue had arisen in New Zealand. That distinguishes this case from the type of situation with which the Privy Council dealt in Singularis. It declined to develop the common law of Bermuda to permit aid of a similar type to be granted.

[13] While overruling Cambridge Gas, so far as the particular jurisdiction was exercised in that case, the Privy Council specifically acknowledged that such assistance could be given "within the limits of [the receiving court's] own statutory" powers. I am satisfied that the grant of assistance on "universalist" principles can be exercised when a statute expressly permits that course. In Singularis the criticism of Cambridge Gas (and the decision of the Supreme Court of Bermuda from which the appeal was brought) was based on a view that those Courts had engaged in illegitimate judicial legislation by purporting to extend the boundaries of the common law to achieve that goal.

Effectively Heath J in Re Batty distinguished the decision in Singularis on the basis that its criticism of Cambridge Gas was ring-fenced to the exercise of an "illegitimate" common law power by a court to assist foreign a foreign liquidation. ${ }^{81}$ If the Court was exercising a statutory power to provide assistance, then the restrictive approach of Lord Sumption, who gave the majority judgment in Singularis, did not apply and therefore a court from taking the wider universalist approach to any CBI application if a court is exercising a power permitted by statute. Applying this rationale to the facts in Re Batty, the Court first noted that s 8(3) provides a court has the same powers as it would have in a domestic insolvency matter. As s 171 of the Insolvency Act 2006 provides that an Assignee has powers to require any person to handover documents relating to the bankrupt's property, the Court was willing to make the requested order in relation to the bankrupt's bank accounts.

The only other decisions to consider s 8 to date a series of orders in Leeds $v$ Richards. ${ }^{82}$ This case involved similar facts to Re Batty and was also decided by Heath J. The specific form of assistance requested by the English court was for the High Court to exercise its powers conferred on the Official Assignee (OA) by ss 165(1) and 171 of the Insolvency Act 2006 to obtain information from New Zealand solicitors relevant to the administration of the bankrupt's estate. ${ }^{83}$ Although it was alleged that some of the information held by the solicitors might be legally privileged, a fact that cannot be waived by the $\mathrm{OA},{ }^{84}$ Heath $\mathrm{J}$ was willing to provide assistance applying the same rationale as Re Batty, subject to a court appointed agent first determining the status of the privileged documents. ${ }^{85}$

Accordingly, although the UK decisions in Rubin v Eurofinance SA, and to a lesser extent, the Privy Council decision in Singularis, represent a retreat from high-water mark ${ }^{86}$ of the principles of universality as represented by the pronouncements of Lord Hoffmann in Cambridge Gas, the courts in New Zealand have continued to regard these pronouncements as informing its discretion under s 8 of the ICB Act. In the three cases to date to consider the discretion in s 8 , the courts have agreed to provide assistance. However, as discussed in the next part, there are certain benefits that accrue to applications subject to Sch 1 of the Model Law that do not apply to applications under s 8 These issues are discussed in the next part of this article.

\section{IsSUes With ApPLication Under s 8 OF Insolvency (Cross-Border) ACt 2006}

\section{A. Disadvantages of Applications for Assistance Outside of the Sch 1 Model Law}

It may be just a coincidence that a significant number of the applications to New Zealand courts for inward assistance since the ICB Act has been enacted have fallen outside of the Sch 1 Model law jurisdiction.

\footnotetext{
${ }^{81}$ Singularis Holdings Ltd v PricewaterhouseCoopers [2015] AC 1675; [2014] UKPC 36.

${ }^{82}$ Leeds v Richards [2016] NZAR 1405; [2016] NZHC 2314. See also Leeds v Richards [2016] NZHC 2248; Leeds v Richards [2016] NZHC 3039.

${ }^{83}$ Leeds v Richards [2016] NZAR 1405, [37]; [2016] NZHC 2314.

${ }^{84}$ See Wong v Official Assignee [1997] NZFLR 300 (HC), 304-305, applying Re Konigsberg (A Bankrupt) [1989] 1 WLR 1257 (Ch); Kupe Group Ltd v Auckland City Council (1989) 2 PRNZ 60 (HC).

${ }^{85}$ Leeds v Richards [2016] NZAR 1405; [2016] NZHC 2314.

${ }^{86}$ Heath and Whale on Insolvency, n 26.
} 
The three cases discussed above all have related to a debtor who has business operations spread over several countries or states and illustrate the difficulties of applying in practice the definitions of "centre of main interest" and "an establishment" in the Sch 1 Model Law, which are based on the UNCITRAL Model Law. If this trend continues, it may be necessary to consider amending the definitions as there are positive benefits for an overseas proceeding being subject to the Sch 1 Model Law regime. Article 20 states that upon recognition there is an automatic stay on individual proceedings against a debtor's assets and a stay on execution against a debtor's assets. In addition, the right to transfer, encumber or otherwise dispose of any assets of the debtor is suspended. With respect to foreign non-proceedings, recognition does not give rise to any automatic consequences. Article 21 does however provide that upon the recognition by the High Court of a foreign proceeding, whether main or non-main, where necessary to protect the assets of the debtor or the interests of the creditors, the Court may, at the request of the foreign representative, grant any appropriate relief. Article 21(1) provides that such relief may include:

(a) staying the commencement or continuation of individual actions or individual proceedings concerning the debtor's assets, rights, obligations, or liabilities, to the extent they have not been stayed under paragraph (1)(a) of article 20;

(b) staying execution against the debtor's assets to the extent it has not been stayed under paragraph (1)(b) of article 20;

(c) suspending the right to transfer, encumber, or otherwise dispose of any assets of the debtor to the extent this right has not been suspended under paragraph (1)(c) of article 20;

(d) providing for the examination of witnesses, the taking of evidence, or the delivery of information concerning the debtor's assets, affairs, rights, obligations, or liabilities;

(e) entrusting the administration or realisation of all or part of the debtor's assets located in New Zealand (f) $\ldots$ to the foreign representative or another person designated by the Court;

Accordingly, there are automatic benefits for an overseas proceeding if the proceeding falls within the scope of the Sch 1 Model Law. However, for many overseas proceedings, especially in respect of bankruptcy proceedings in relation to individuals with global business interests, the proceedings will not satisfy the definition of "foreign non-main proceedings" in order for the Model Law in Sch 1 to apply.

One solution may be to adjust the definition of "foreign non-main proceeding" in the Model Law in Sch 1, as has occurred in Canada. Section 45 of the Bankruptcy and Insolvency Act RSC 1992, c B-2 and s 268 of the Companies' Creditors Arrangement Act RSC c C-35 were amended to define foreign non-main proceedings as foreign proceedings that are not foreign main proceedings ${ }^{87}$ This removes the requirement that a debtor must have an establishment in a foreign jurisdiction as a precondition for recognition of insolvency proceedings originating from that jurisdiction.

\section{B. Remit of Funds and Assets}

Another advantage of a foreign proceedings being subject to the Sch 1 Model Law relates to the jurisdiction for the remit of funds and assets offshore. In Art 21(2) of Sch 1, upon recognition by the High Court of a foreign proceeding, whether main or non-main, the Court may, at the request of the foreign representative, entrust the distribution of all or part of the debtor's assets located in New Zealand to the foreign representative or another person designated by the Court, provided that the Court is satisfied that the interests of creditors in New Zealand are adequately protected. Entrusting the distribution of assets located in New Zealand to a foreign representative is a substantial form of relief, but local creditors are protected by the proviso that their interests must be adequately protected. ${ }^{88}$

\footnotetext{
${ }^{87}$ Bill C-55, Statutes of Canada, 2005 c 47.

${ }^{88}$ Insolvency (Cross-border) Act 2006 (NZ) Sch 1, Art 21(2). Also see Akers v Deputy Commissioner of Taxation (2014) 223 FCR 8, [58]; [2014] FCAFC 57 with respect to the equivalent provision in the Cross-Border Insolvency Act 2008 (Cth). Allsop J on behalf of the Court noted that the existence of Art 21 is important as it reflects a degree of modified universalism In the Model Law in that it contains an express recognition of the need to protect adequately the interests of local creditors. In this case, the Federal Court of Australia upheld orders of a lower court refusing to remit funds to foreign representatives in the Cayman Islands as the Australian Tax Office had a claim against such funds and proof of such a claim would not have been accepted under the laws applying in the Cayman Islands.
} 
However, the source of the jurisdiction to hand over assets to a foreign representative when the application originated in proceedings that were neither foreign main or foreign non-main proceedings under $\mathrm{s} 8$ is unclear. In Williams $v$ Simpson, interim orders under Art 19 of Sch 1 had already been issued before the decision on the recognition application was heard. As a result, search warrants had been issued to the Court's agent, the OA, to search premises for concealed bullion and subsequently for documents and computer data relevant to the subject of the warrant and foreign currency. ${ }^{89}$ As a result considerable bullion, foreign currency and relevant documents had been seized and held pending the outcome of the recognition application. Also, the debtor's rights to transfer or otherwise dispose of assets had been suspended. After Heath $\mathrm{J}$ had determined that the Court could grant assistance under s 8, his Honour considered that its discretion should also be informed by Art 22(1) in that the Court "must be satisfied that the interests of the creditors and other interested persons, including the debtor, are adequately protected" before making any orders. ${ }^{90}$ After taking all of these factors into account, his Honour then authorised the OA to take possession of the items seized and to preserve the interests of all parties while certain ownership issues were resolved. Interestingly, while Heath J identified a number of provisions of the Insolvency Act 2006 that authorised the OA to act in respect of the collection of property, the Court did not identify the source of the OA's authority to remit funds back to the English representative at the end of these procedural steps if that was required. In a subsequent decision in the same matter, Heath $\mathbf{J}$ discussed the appointment of an examiner, as an exercise of the court's inherent jurisdiction. He noted that while s 8(3) of the ICB Act declares that a court only has ability to exercise powers in respect of an application for assistance as if the application had arisen within its own jurisdiction, there was nothing in the wording in s 8 that "would oust the inherent jurisdiction of this Court to provide relief, provided (otherwise) that jurisdiction was available". ${ }^{91}$

As inherent jurisdiction only gives the Court power to undertake matters incidental to that which the Court has actual jurisdiction, ${ }^{92}$ inherent jurisdiction is not the solution to the question of what is the source of the jurisdiction for a New Zealand court to authorise the remission of funds or property to a foreign representative, when the application for remission is not subject to the Sch 1 Model Law. Another possibility is that the source of this power is the common law. As discussed above, the Privy Council decision in Singularis is now the principal decision on the scope of common law judicial assistance. Although Heath $\mathrm{J}$ in Re Batty distinguishes the application of Singularis on the facts of Re Batty, it is submitted that in cases when the common law is the underlying source of a court's power, following Singularis a foreign liquidator would not able to take control of New Zealand based assets and distribute them overseas in all cases. McCormack and Hargovan, writing in 2015 about the "aid and auxiliary" provision in s 581 of the Corporations Act 2001, observed that the decision in Singularis "provides no support for the proposition that an Australian court would have inherent jurisdiction to remit assets to a foreign insolvency proceeding whose substantive law of distribution is different from that in Australia". ${ }^{93}$ A similar observation can be made in respect of the New Zealand law on this issue.

\section{CONCLUSION}

The New Zealand Law Commission observed in 1999 that New Zealand has long taken a pragmatic approach to CBI issues ${ }^{94}$ and this attitude is reflected in the policy decision to include a broad aid and assistance power in s 8 of the ICB Act. However, the Sch 1 Model Law needs to be the central pathway for New Zealand courts to provide assistance and New Zealand courts should continue with the approach

\footnotetext{
${ }^{89}$ See Williams $v$ Simpson (No 5) [2011] 2 NZLR 380 (HC), [8]-[16] for the background to the proceedings.

${ }^{90}$ Williams $v$ Simpson (No 5) [2011] 2 NZLR 380 (HC), [85].

${ }^{91}$ Williams v Simpson (No 7) HC HAM CIV2010-419-1174 (10 November 2010) [18]-[21]. Inherent jurisdiction arose in the case under Judicature Act 1908 (NZ) s 26I(3) and this provision conferred on Judges "all the jurisdiction and powers of the Court to deal with ... matters incidental to the matter" over which the Judge has jurisdiction.

${ }^{92}$ See Re Roslea Path Ltd (in liq) CIV 2005-470-611, 17 for a discussion of the inherent jurisdiction of a court in respect of statutory powers in an insolvency context.

${ }^{93}$ McCormack and Hargovan, n 51, 402.

${ }^{94}$ New Zealand Law Commission, n 3, 26.
} 
of relegating assistance under s 8 to only when an application is ineligible for assistance under the Model law. Foreign representatives should not be able to decide to opt for assistance under s 8 without judicial confirmation that the foreign proceedings in question do not qualify as foreign main proceedings or foreign non-main proceedings under Sch 1.

The pragmatic approach can also been seen in the approach by New Zealand courts to ring-fence the recent UK decisions to applications to the Court which are solely reliant upon common law principles. This approach has allowed New Zealand courts to continue to be willing to provide assistance as demonstrated by the fact that in all three cases discussed in this article the Court has agreed to provide the requested aid and to recognise the foreign proceedings. Although, it is worth noting that the proceedings in all three cases originated from English courts, which has a similar legal system to that of New Zealand. The Gainsford decision in Australia suggests that Australian courts are likely to take a similar universalist approach to aid and assistance applications, irrespective of recent changes in the common law.

Finally, although s 8 provides a gateway to provide assistance in response to inwards requests, this article argues that there are limits to the form of assistance the Court is able to provide under this provision. This limitation together with the narrowness of the definition of foreign non-main proceeding in the Model Law in Sch 1 support the desirability of New Zealand revisiting the regulation of CBIs. However, as evidenced by New Zealand delaying the implementation of the ICB Act into New Zealand until after Australia had enacted the Cross-Border Insolvency Act 2008, a harmonised approach to CBI regulation on both sides of the Tasman sea is essential. Any amendments to the current New Zealand regime should only be undertaken after careful consideration. 